\title{
D Vitamininin Biyolojisi ve Doğal Kaynakları
}

\author{
Gülşah ÇOBANOĞLU ÖZYiĞiTOĞLUiD1 \\ ${ }^{1}$ Marmara Üniversitesi, Fen-Edebiyat Fakültesi, İstanbul \\ Geliş Tarihi (Received): 09.08.2020, Kabul Tarihi (Accepted): 25.10.2020 \\ $\square$ Sorumlu Yazar (Corresponding author): gcoban@marmara.edu.tr \\ (C) +902167770000 㕶 +902167773201
}

$\overline{\text { ÖZ }}$

Dünya genelinde D vitamini eksikliği ve yetersizliği önemli sağlık sorunları arasındadır. Güneşe maruziyet ile (belirli dalga boyundaki ultraviyole UVB ışınları) sentezlenen D vitamininin kalsiyum ve fosfat metabolizmalarını düzenleyici rolünün yanında, doğal koruma, pek çok kronik ve otoimmün hastalığı önleme ve geciktirmede görev yaptığı bilinmektedir. İnsanların ve diğer canlıların yaşamlarını sağlıklı ve güçlü sürdürebilmeleri için belirli seviyede tutulması gereken D vitaminine intiyaçları vardır. Bu derleme çalışmasında, D vitamininin sağlık için önemine kısaca değinildikten sonra, insanların D vitamini kaynağı olarak diğer organizmalardan faydalanabilmesi hedefine yönelik olarak, özellikle doğadaki $D$ vitamini metabolitleri bakımından zengin canlılar ile ilgili bugüne kadar literatürde yer alan çalışmalara dayanan bilgiler sunulmuştur. Bu konuda ekolojik verilerin oldukça az olduğu görülmekle birlikte, bitkisel ve hayvansal doğal kaynaklar olarak yararlanabilecek $D$ vitamini sentezleyen ve biriktiren canlı türleri hakkında çeşitli bulgular derlenmiştir. Yapılan çalışmalarda, UVB etkisiyle yüksek miktarda D vitamini üreten canlılar arasında fitoplanktonik algler, Ren geyiği likeni, mantarlar ve D vitamini biriktiren balıklar ve likenler sayılmaktadır. Bunların yanı sıra bu çalışmada, D vitaminin biyolojisi ve fotokimyasal sentez metabolizması ve $D$ vitamininin oluşumunu etkileyen biyolojik ve çevresel faktörler hakkında açıklayıcı bilgilere yer verilmiştir. Bu derleme, insanlar için öngörülebilir D vitamini kaynağı sağlayabilecek canlıların potansiyeline odaklanmaktadır.

Anahtar Kelimeler: Doğal D3 kaynakları, D vitamini, ergosterol, kolekalsiferol, UVB

\section{Biology and Natural Sources of Vitamin D}

\begin{abstract}
Vitamin D deficiency and insufficiency are among the important health problems worldwide. Vitamin D, which is synthesized by sun exposure (specific wavelength ultraviolet UVB rays), is known to act as a natural protector, preventing and delaying many chronic and autoimmune diseases, as well as its regulatory role in calcium and phosphate metabolism. People and other creatures need vitamin D to keep their lives healthy and strong. In this review, after briefly mentioning the importance of vitamin $D$ for health, information based on the studies in the literature has been presented about the creatures rich in vitamin D metabolites, especially for the purpose of people to benefit from other organisms as a source of vitamin D. Although there are few ecological data on this subject, various findings have been compiled about the species that synthesize and accumulate vitamin D, which we can use as natural sources. In the studies done, phytoplanktonic algae, reindeer lichen, fungi and also fish and lichens accumulating vitamin $D$ are among the creatures that produce high amounts of vitamin D with the effect of UVB. In addition, in this study, explanatory information on the photochemical synthesis metabolism and biology of the vitamin $D$ and the biological and environmental factors affecting the formation of vitamin $D$ are included. This review focuses on the potential of living things that can provide a predictable vitamin D source for humans.
\end{abstract}

Keywords: Natural $D_{3}$ sources, vitamin D, ergosterol, cholecalciferol, UVB 


\section{Giriş}

D vitamini; vücutta uzun süre depolanabilen yağda çözünen vitaminlerden biridir. Aynı zamanda endojenik sentezlenebilen bir steroid olduğu için hormon olarak kabul edilmektedir. Yeryüzünde yaşamın başlangıcından bu yana üretilen $D$ vitamini, güneş vitamini olarak tabir edilir, çünkü büyük kısmı (\%90-95) güneş etkisinde sentezlenir (Akkoyun ve ark., 2014). Derideki $D_{3}$ provitamini olan 7-dehidrokolesterol (7-DHK) güneş ışığına maruz kaldığında Ultraviyole B (UVB) ışınlarını emerek previtamin $D_{3}$ 'e ve onun termal foto-izomerizasyonu $\left(\geq 25^{\circ} \mathrm{C}\right)$ (Holick ve ark., 1995) sonucunda $D_{3}$ vitaminine dönüştürülür. Dolayısıyla insan yaşamının devam edebilmesi için gerekli koşullardan biri de güneş ışınlarıdır. D vitaminiyle ilgili çok sayıda çalışmaya dayalı olarak (Göring, 2018), "Güneş ışığı spektrumunun mor ötesi-ultraviyole (UV) kısmı olmasaydı dünyada hiç $D$ vitamini bulunmayacaktı" şeklinde bir sonuca varmıştır. Çünkü 7-DHK molekülündeki B halkasının UVB ışınlarına karşılık gelen 282-310 $\mathrm{nm}$ aralığındaki fotonların enerjisi (18 $\mathrm{mJ} / \mathrm{cm}^{2}$ ) ile açılabildiği varsayılmaktadır.

Güneş kaynaklı D vitamini sentezi mevsim, günün saati, enlem, rakım, hava kirliliği, cilt pigmentasyonu, cilt tipi, güneş koruyucu kullanımı, cam ve plastikten geçme, vücut sıcaklığı ve yaşlanma gibi çevresel faktörlerden büyük ölçüde etkilenmektedir (Wacker ve Holick, 2013; Chubarova ve Zhdanova, 2013). Deride yapılan veya besin maddelerinden alınan $\mathrm{D}$ vitamini biyolojik olarak aktif değildir. $\mathrm{D}$ vitamini karaciğer ve böbreklerde sırasıyla 25-hidroksivitamin D [25(OH)D]'ye ve biyolojik olarak en etkin formu olan 1,25-dihidroksivitamin $D$ $\left[1,25(\mathrm{OH})_{2} \mathrm{D}\right]$ 'ye metabolize edilmektedir (Fidan ve ark., 2014).

D vitamininin önemli sağlık yararları olduğuna dair kanıtları gösteren birçok araştırma bulunmaktadır (Dusso ve ark., 2005; Holick, 2009; Grant ve ark., 2015). D vitamini optimal konsantrasyonlarının korunması otoimmün hastalıklar, kardiyovasküler hastalıklar, birçok kanser türü, demans, tip 1 ve 2 diyabet ve solunum yolu enfeksiyonlarının risklerini ve şiddetini azaltır. Gelişmiş diş ve ağız sağlığı ile gelişmiş fiziksel performans diğer faydaları arasında yer almaktadır (Grant ve ark, 2015). D $D_{3}$ vitamininin aktif formu olan $1,25(\mathrm{OH})_{2} \mathrm{D}$; hipofiz, yumurtalıklar, cilt, mide, pankreas, timus, meme, böbrek, paratiroid bezleri, periferik lökositler gibi farklı vücut hücrelerinde D vitamini reseptörleri ile birleşerek yaklaşık 200 geni kontrol etmektedir (Holick, 2009).

Illk olarak D vitamini eksikliğinin ortaya çıkmasında sanayi devriminin etkili olduğu görülmüştür. 17. yüzyılda, Avrupa'daki büyük şehirlerde, endüstriyel gelişimin yol açtığı hava kirliliği örtüsü nedeniyle yeterli güneş ışığından mahrum kalınması sonucunda, raşitizm hastalığının hızla arttığı fark edilmiştir. Ancak 70 yıl kadar sonra kemik sağlığının $D$ vitaminiyle ilişkili olduğu anlaşılmıştır. Bazı ülkelerde uygulanan UVB ışınlaması veya $D_{2}$ vitamini ile güçlendirilen süt vb. ürünlerle raşitizmler ortadan kaldırılmıştır. Hatta bu takviyeler fazla popüler hale gelerek bir dönem yüksek dozdaki $D$ vitamini başka zihinsel ve bedensel sağlık problemlerine neden olmuştur. Bugün sütün $D$ vitamini ile takviye edilmesine sadece birkaç ülkede izin verilmektedir (Wacker ve Holick, 2013).

Günümüzde 1 milyara yakın kişide olduğu tahmin edilen D vitamini eksikliği küresel sağlık sorunlarından biridir. En fazla Kuzey Asya ve Ortadoğu bölgelerinde olmak üzere (Öncül Börekçi, 2019) dünyanın birçok bölgesinde, güneşe maruz kalma süresi ve yaşam tarzlarına bağlı yetersiz UVB nedeniyle $D$ vitamini eksikliği yaygın olarak görülmektedir. Bu durumlarda, D vitamininin gIdalardan veya besin takviyelerinden alınması sağlık için gerekli D vitamini seviyesini korumak için oldukça önemlidir. Yüksek miktarda $D$ vitamini sağlayabilen gıdalar arasında yağlı balık, balık ciğeri, balık yağları, bazı etler, yumurta, tereyağı, süt ve süt ürünleri, mantar ve takviye edilmiş gıdalar gelmektedir (Black ve ark., 2017). Ayrıca D vitamini düzeyi toplumların beslenme kültürü ile yakın ilişkilidir. Örneğin Kozlov ve ark. (2014)'nın Kuzey Rusya'da etnik gruplarla yaptıkları çalışma, Nenets ve Komi yerli Arktik halkının büyük miktarda geyik eti, ren geyiği yağı ve balık içeren geleneksel diyetinin batı tarzı diyetlere göre $D$ vitamini eksikliğini etkili bir şekilde önlediğini göstermiştir.

Bilimsel otoriteler optimum sağlık için 25(OH)D konsantrasyonlarının, 800 ila 4000 IU günlük $D_{3}$ vitamini ve UVB radyasyonuna karşı duyarlı güneş maruziyetiyle elde edilebilen 75 ila $125 \mathrm{nmol} / \mathrm{L}$ aralığında olmasını önermektedir (Grant ve ark., 2015). Bunun yanında yüksek konsantrasyonların potansiyel riskleri bulunmaktadır (Holick, 2009).

Farklı gıda maddelerinde $D$ vitamini $\left(D_{2}\right.$ ve $\left.D_{3}\right)$ ve bunların provitaminleri ile ilgili olarak, D vitamini alımının insan vücudu üzerindeki etkileri ve fizyolojik olarak aktif $D$ vitamini formunun hücresel etkileri konusunda çok sayıda araştırma yapılmıştır. D vitamini için önemli bir kaynak balıktır ancak balıklar D vitamini veya provitamin D'yi sentezleyemezler, mikroalglerden dolayı biriktirirler. Hangi tür veya planktonik alg gruplarının $D$ vitamini sentezleyebileceği hakkında ise pek az şey bilinmektedir. Bitki bilimcilerinin de ilgisini çeken D vitamini, bazı yüksek bitkiler tarafından sentezlenir ve büyüme maddesi olarak işlev görür. Provitamin $D_{2}$ (ergosterol) birçok mantar tarafından sentezlenir ve bu durum bitki-mantar simbiyozuna bir miktar açıklık getirmektedir. Ren geyiği likeninin oldukça yüksek miktarlarda $D_{2}$ ve $D_{3}$ vitamini 
içerdiği gözlemlenmiştir (Björn ve Wang, 2000; Keegan ve ark., 2013).

Doğada D vitaminince zengin biyolojik kaynakların neler olabileceği, hangi organizmalarda ne kadar sentezlendiği vb. bilgiler henüz yeterli miktarda olmayan çalışmalara dayanmaktadır. Ekolojik bağlamda $D$ vitamini ile ilgili neredeyse hiçbir çalışma yoktur. Bu derleme insanlar için doğal $D$ vitamini sağlayacağı öngörülebilen canlıların potansiyeline odaklanmıştır. Bu makalede genel anlamda hayvansal ve bitkisel tüm canlı gruplarındaki D vitamini içerikleri hakkında literatürden elde edilen bilgiler derlenerek sunulmuştur.

\section{VITAMINININ BIYOLOJISi}

Yeterli miktarda güneş ışığına maruz kalabilen organizmaların $D_{3}$ vitamini üretme yeteneği, $D$ vitamininin aslında sadece bir vitamin olmadığını göstermektedir. Günümüzde $D$ vitamininin 1,25-dihidroksivitamin $D 3$ steroid hormonuna veya kalsiterole (D vitamininin aktif formu) metabolize olduğu anlaşılmıştır (Gürbüz ve ark., 2015). Bu D vitamini hormonu, biyolojik tepkilerden sorumlu hedef genlerin transkripsiyonlarını değiştiren hücresel $D$ vitamini reseptörünü aktif hale getirmektedir. Diğer bir deyişle $D_{3}$ vitamini, hücresel hormon reseptörü ile çalışan bir hücresel transkripsiyon düzenleyicisidir. D vitamini sistemi, tek bir reseptör ve liganddan fazlasını içerebilmektedir. $\mathrm{D}_{3}$ vitamini $\left[1,25(\mathrm{OH})_{2} \mathrm{D}_{3}\right]$, dolaşımdaki hormon seviyelerinden bağımsız olarak dokularda da bulunabilir. Örneğin beyinde ve birçok hedef hücrede hidroksilaz enzimlerinin varlığı, hücre proliferasyonu ve farklılaşmasının kontrolünde otokrin / parakrin (salgılandığı hücrede / yakın hücrelerde etkili) olarak $\mathrm{D}_{3}$ 'ün fonksiyonlarını işaret etmektedir. $1,25(\mathrm{OH})_{2} \mathrm{D}_{3}$ 'ün bu lokal üretimi, dolaşımdaki öncü seviyelerine bağlı olarak $D$ vitamini eksikliğinin çeşitli kanserler ve otoimmün hastalıklarla olan ilişkisine olası bir açıklık getirmektedir (Mackay-Sim ve ark., 2004; Dusso ve ark., 2005).

Güneş ışığının cilt üzerindeki etkisiyle üretilen $D_{3}$ vitamini hormonu, ultraviyole B ışınlarının epidermiste bir kolesterol metabolitine etki etmesiyle öncelikle previtamin D olarak üretilir. Karaciğerde ve daha sonra böbrekteki hidroksilasyon, vitaminin en aktif formunu (1,25-dihidroksivitamin D3) oluşturmaktadır (Mackay-Sim ve ark., 2004). UVB etkisi sonucunda deride üretilen $D_{3}$ vitamininin çoğu epidermisdeki canlı hücrelerde yapılmaktadır. Cilt güneş ışığına maruz kaldıktan hemen sonra sabun ve su ile yıkandığında bile $\mathrm{D}_{3}$ vitamininin ciltte kaldığı belirtilmektedir (Wacker ve Holick, 2013).

D vitamini duyarlı biyolojik dokular olan böbrek, kemik, paratiroid bezi ve bağırsak arasındaki etkileşimlerin önemli bir bileşeni $D$ vitamini endokrin sistemidir. Hücre dışı kalsiyum seviyelerini dar sınırlar içinde tutan normal hücre fizyolojisi ve aynı zamanda iskelet bütünlüğü için bu sistem hayati bir süreç teşkil etmektedir. $D$ vitamini duyarlı biyolojik dokular olan böbrek, kemik, paratiroid bezi ve bağırsak arasındaki etkileşimlerin önemli bir bileşeni D vitamini endokrin sistemidir. Hücre dışı kalsiyum seviyelerini dar sınırlar içinde tutan normal hücre fizyolojisi ve aynı zamanda iskelet bütünlüğü için bu sistem hayati bir süreç teşkil etmektedir. Bu nedenle $D$ vitamini endokrin sistemindeki anormallikler, hücre büyümesinin baskılanmasından hipertansiyona, kas fonksiyonlarından enfeksiyonlara, otoimmün hastalıklara ve kansere kadar değişen kalsiyum homeostazı ile bağlantılı bozukluklar ile ilişkilendirilmektedir (Dusso ve ark., 2005). Çok sayıdaki çalışmada D vitamini sistemi ile apoptozun düzenlenmesi, bağışıklık yanıtlarının modülasyonu, derideki farklılaşma ve fonksiyonun kontrolü, renin-anjiyotensin sisteminin kontrolü, insülin salgısının kontrolü, kas fonksiyonunun kontrolü, sinir sisteminin kontrolü gibi geniş bir kapsamda biyolojik doku ve sistemler arasındaki ilişkiler keşfedilmeye devam etmektedir.

\section{Fotokimyası ve Sentez Metabolizması}

D vitaminin ana kaynağı kolesterol olmakla birlikte ultraviyole ışınlarının $D$ vitamini sentezinde önemli rolü bulunmaktadır. Vitamin D sentezi, epidermisde UVB ışınlarının etkisi ile $D_{3}$ provitamini olan 7-dehidrokolesterolün (7-DHK) B halkasının ayrılmasıyla başlamaktadır (Dusso ve ark., 2005). Güneş ışığına maruz kalma sırasında $290-315 \mathrm{~nm}$ dalga boylu güneş radyasyonu cilde nüfuz eder ve proteinler, DNA, RNA ve ayrıca 7-DHK tarafından emilir. Bu ışınlar 7-DHK'nın çift bağlarının aktivasyonuna neden olarak $B$ halkasının açılmasını sağlar ve önce sekosteroid (bölünmüş steroid) olan previtamin $D_{3}$ 'ü oluşturur. Bu öncü $D_{3}\left(25^{\circ} \mathrm{C}\right.$ 'de birkaç gün süren) termal izomerizasyon sonucunda, hızlıca termodinamik olarak kararlı $D_{3}$ vitaminine (kolekalsiferole) dönüşür (Holick, 2009). Oluşan bileşiklerin de UVB absorbe etmesiyle benzersiz biyolojik özelliklere sahip çeşitli foto ürünler meydana gelmektedir. D vitamini sırasıyla deri, karaciğer ve böbrekte metabolize edilmektedir. Özet olarak, epidermal 7-DHK güneşten UVB ışınlarını emdiğinde previtamin $D_{3}$ 'e ve daha sonra deride $D_{3}$ vitaminine dönüşmektedir (Şekil 1).

UV ile indüklenen fotokimyasal reaksiyonda $D$ vitaminine benzer maddelere dönüştürülebilen farklı bir grup steroller de bulunmaktadır: 22,23-dehydroergosterol $\rightarrow$ vitamin $\mathrm{D}_{4}$; 7-dehydrositosterol $\rightarrow$ vitamin $\mathrm{D}_{5}$; 7-dehydrostigmasterol $\rightarrow$ vitamin $D_{6}$; 7-dehydrocampesterol $\rightarrow$ vitamin $D_{7}$ (Göring, 2018).

D vitamini, 25. karbonun 48 saat içinde karaciğerdeki mikrozomal 25-hidroksilaz enzimi ile hidroksillenmesiyle kararlı bir öncü olan 25 hidroksivitamin D3'e [25(OH)D 3 ] 
dönüşür. Vücuttaki $D$ vitamini deposunu en iyi yansıtan $25(\mathrm{OH}) \mathrm{D}_{3}$ formudur (Göring, 2018). 25(OH) $\mathrm{D}_{3}$ daha sonra 1-alfa hidroksilaz enzimi ile böbrekteki renal proksimal tübüllerde aktif formu olan 1,25 dihidroksivitamin D3 [1,25(OH $\left.)_{2} \mathrm{D} 3\right]^{\prime}$ 'e dönüştürülür. Bu D vitamini aktivasyonundaki son adımdır. Böbrekteki distal tübüllerden sentezlenen hidroksilaz enziminin aktivitesi paratiroid hormon (PTH), kalsiyum ve fosfat seviyelerine bağlı olarak düzenlenmektedir (Henry, 2011; Yılmaz ve Yılmaz, 2013). PTH, böbreklerde fosfat geri emiliminde bir azalmaya neden olarak kandaki fosfor seviyesinin düşmesine neden olur. Bu ince etki, hücre dışı boşlukta yetersiz bir kalsiyum-fosfor ürününe yol açarak yeni oluşan kolajen matriksinde bir mineralizasyon bozukluğuna neden olmaktadır. İskeletten kalsiyumun mobilizasyonunu arttırması ve aynı zamanda yeni üretilen kolajen matriksinde bir mineralizasyon kusuruna neden olmasından dolayı, PTH düzeylerindeki herhangi bir belirgin artış, D vitamini eksikliğini saptamak için bir biyobelirteç olarak kullanılabilmektedir. 1,25(OH $)_{2}$ D'nin ana işlevi, dolaşımda sıkı bir kalsiyum ve fosfor homeostazı sağlamaktır (Pludowski ve ark., 2018).

$1,25(\mathrm{OH})_{2} \mathrm{D}$ ince bağırsak, böbrek ve diğer dokularda bulunan vitamin $\mathrm{D}$ reseptörleri ile aktif fonksiyon gösterir. Kan dolaşımındaki D3 vitamini, bağırsak epitelinden kalsiyum ve fosfat emilimini kolaylaştırır; böylece kalsiyum ve fosfor metabolizmasını düzenlemeye yardımcı olur (Mackay-Sim ve ark., 2004; Pludowski ve ark., 2018). Bağırsakta kalsiyum absorbsiyonunu arttırıp böbreklerde kalsiyum kaybını azaltarak kandaki kalsiyum düzeyinin korunmasını sağlar. $1,25(\mathrm{OH})_{2} \mathrm{D}$ vitamininin hücre proliferasyonunu inhibe edici, insülin üretimini uyarıcı biyolojik etkileri de rapor edilmiştir. Birçok dokuda bulunan 24 hidroksilaz enzimi tarafından inaktive edilen D vitamini metabolitleri safra yoluyla atılmaktadır (Fidan ve ark., 2014).

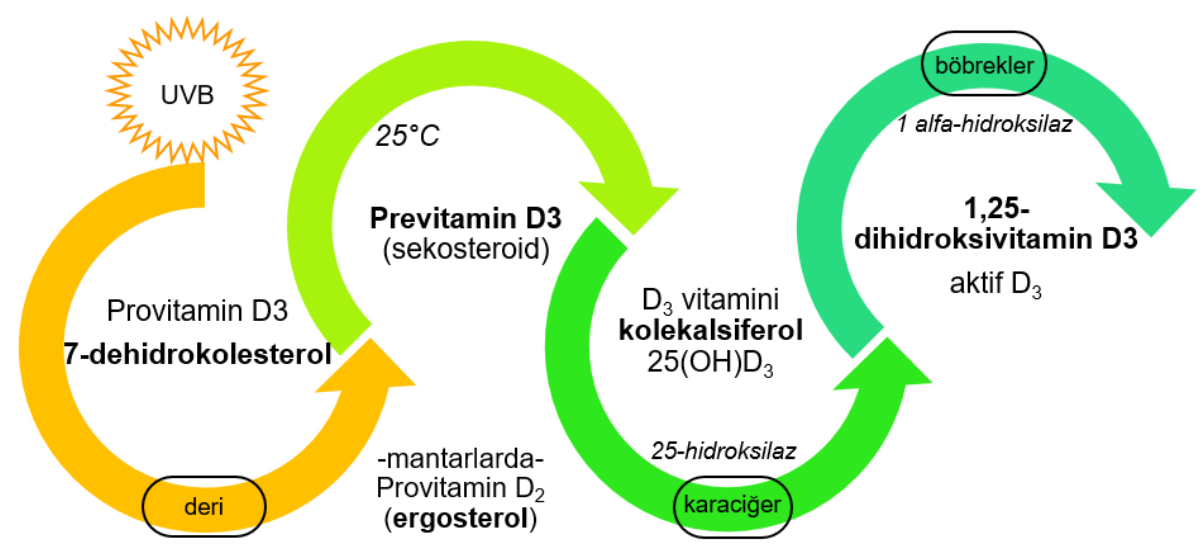

Şekil 1. D vitaminin biyosentezi

Vitamin D'nin majör metabolitlerinin, $25(\mathrm{OH}) \mathrm{D}_{3}$, $1,25(\mathrm{OH})_{2} \mathrm{D}_{3}$ ve $24,25 \mathrm{OH}_{2} \mathrm{D}_{3}$, kan beyin bariyerini geçtiği ve beyinde bir metabolizmasının olduğu tespit edilmiştir (Eyles ve ark., 2013).

$D_{3}$ vitamini (kolekalsiferol) insan derisinde sentezlenirken, $D_{2}$ vitamini (ergokalsiferol) maya ve mantarlardan gelmektedir. Çoğu D vitamini takviyesi $\mathrm{D}_{3}$ (kolekalsiferol) vitaminidir ve beslenme yolu ile alınan D2 ve D3 vitaminlerinin emilimi bağırsaklarda gerçekleşmektedir. $D_{2}$ ve $D_{3}$ ile desteklenen sağlıklı yetişkinleri inceleyen bir çalışmada, $D_{3}$ vitamininin $25(\mathrm{OH}) \mathrm{D}$ konsantrasyonlarını artırma ve koruma konusunda \% 87 daha güçlü olduğu görülmüştür (Grant ve ark., 2015).

Previtamin $D_{3}$ 'ün deride $D_{3}$ vitaminine dönüşmesi vücut sıcaklığında günler alabilmektedir. Ayrıca bu, poikiloterm (soğukkanlı) omurgalılar için önemli bir sorundur, çünkü daha düşük bir dış sıcaklıkta deride üretilen previtamin $D_{3}$ 'ün $D_{3}$ vitaminine dönüşmesi çok daha uzun sürmektedir. $\mathrm{D}_{3}$ vitamini termodinamik olarak daha kararlı ve daha esnek olduğundan, plazma zarından hücre dışı boşluğa atılmakta ve dermisde kılcal yatağa yayılan D vitamini proteine bağlanarak karaciğere taşınmaktadır (Wacker ve Holick, 2013).

UV ışınlarının yeryüzüne ulaşmasında klimatolojik faktörler; bulutlar, aeresoller, gökyüzünün berraklık derecesi önemli parametrelerdir (Chubarova ve Zhdanova, 2013). Hem çocukların hem de yetişkinlerin $D$ vitamini düzeyinde mevsimsel farklılıkların ve coğrafi enlemin dramatik bir etkiye sahip olduğu rapor edilmiştir. Ekvatorun yakınındaki bölgelerde yaşayan çocuklarda, ergenlerde ve yetişkinlerde kanda $25(\mathrm{OH}) \mathrm{D}$ seviyelerinde ekvatorun kuzey ve güneyinde yaşayanlara kıyasla anlamlı bir artış olduğu görülmüştür. Bununla birlikte Avrupa'nın 
en yüksek enlemlerinde yaşayanların da $25(\mathrm{OH}) \mathrm{D}$ dolaşım konsantrasyonlarının yüksek olduğu bildirilmiştir. Bu durum, muhtemelen yılın yarısından fazlasında önemli miktarda $D_{3}$ vitamini yapamayan insanların, yağlı balıklar da dahil olmak üzere $D$ vitamini açısından zengin yiyecekler yiyerek uyum sağladığı şeklinde (Wacker ve Holick, 2013).

$D_{3}$ vitamini deride provitamin $D_{3}$ 'ün fotokimyasal dönüşümü ile sentezlenmekte, gerekli ışınlar ise sadece $35^{\circ}$ enlemin altında kalan yerlerde tüm yıl boyunca yayılmaktadır. Ancak ne yazık ki, çok az gıda kaynağı doğal olarak $D$ vitamini içermekte ve sonuç olarak genel popülasyon gereksinimlerini karşılayamamaktadır (Jäpelt ve Jakobsen, 2013).

UV maruziyeti ile cilt kanseri riski de artarken, D vitamini yönünden zengin yiyecek alımının, koyu tenli insanlarda beyaz deriye göre daha düşük $25(\mathrm{OH}) \mathrm{D}$ konsantrasyonlarına yol açtığı, aynı miktarda D vitamini üretmek için koyu ten açık ten renginden yaklaşık altı kat daha fazla UVB'ye intiyaç duyduğu belirtilmiştir (Grigalavicius ve ark., 2013).

\section{ViTAMINININ SAĞLIK IÇíN ÖNEMi}

Güneş ışınları ve D vitamini sağlıklı ve güçlü bir immün sistem için olmazsa olmazdır. D vitamininin en önemli işlevi omurgalıların kalsiyum dengesinin sürdürülmesidir. D vitamini yetersizliği hipertansiyon, otoimmün hastalıklar, diyabet ve kanser riskinde artışla (WoloszynskaRead ve ark., 2011) bağlantılıdır. Bu nedenle, optimal sağlık için bir gereklilik olarak D vitamini hakkında artan bir farkındalık bulunmaktadır (Jäpelt ve Jakobsen, 2013).

D vitamini eksikliği; 25(OH)D düzeyinin $20 \mathrm{ng} / \mathrm{mL}$ 'den az olması, D vitamini yetersizliği 21 ile $29 \mathrm{ng} / \mathrm{mL}$ arasında olması ve $D$ vitamini toksik seviyesi ise $150 \mathrm{ng} / \mathrm{mL}$ 'den fazla olması ile ifade edilmektedir (Fidan ve ark., 2014). Yaş, vücut ağırlığı, hastalık durumu ve etnik kökene bağlı değişebilen $D$ vitamini dozunun yıl boyunca 30 $\mathrm{ng} / \mathrm{mL}$ 'den yüksek tutulması $(40-60 \mathrm{ng} / \mathrm{mL})$ tavsiye edilen yeterli düzey olarak kabul edilmektedir (Pludowski ve ark., 2018). D vitamini suda erimediği için fazlası idrarla atılamaz ve bu nedenle gereksinimden fazlası sakıncaIıdır. D vitamini eksikliğinin kemiklerde yumuşamaya, kemik ve diş yapısında bozulmalara neden olduğu bilinmektedir. Çocuklarda rikets, erişkinlerde ise osteomalazi klinik tablosuna neden olduğu, aynı zamanda osteoporoz, düşme ve kırıklar için bir risk faktörü olarak tanımlandığı belirtilmektedir.

D vitamini $\left(D_{2}, D_{3}\right.$ 'ü veya her ikisi), alınan besinlerden kalsiyum ve fosfor emmesi için ince bağırsağı uyarmada gereklidir. İlk önce karaciğerde 25-hidroksivitamin D'ye ve daha sonra böbreklerde 1,25-dihidroksivitamin D aktif formuna dönüşür. $1,25(\mathrm{OH})_{2} \mathrm{D}$ dolaşıma girer ve kalsiyum düzenleyici hedef dokulara, ince bağırsağa ve kemiğe gider. İnce bağırsak emici hücreleri, $1,25(\mathrm{OH})_{2} \mathrm{D}$ 'yi spesifik olarak bağlayan ve daha sonra bağırsak kalsiyum emilimini arttırmak için D vitaminine duyarlı genleri aktive eden spesifik reseptörler (D vitamini reseptörleri) içermektedir (Holick, 2009).

Kalsiyum diyetinin vücudun ihtiyacını karşılamak için yetersiz olduğu durumda, $1,25(\mathrm{OH})_{2} \mathrm{D}$ kemiğe giderek kemik oluşturan hücrelerle (osteoblastlar) etkileşir ve kemikteki emici hücrelerin (osteoklastlar) oluşumunu uyarır. Bu işlem, kalsiyum depolarının kemikten çıkarılmasından ve kan kalsiyumunun normal aralıkta (kalsiyum homeostazı) korunması için kana bırakılmasından sorumlu olan osteoklastik aktivitede bir artışla sonuçlanmaktadır. Bu nedenle D vitamininin ana fizyolojik rolü, temel metabolik fonksiyonları korumak için hücre içi ve hücre dışı kalsiyum konsantrasyonlarını korumaktır (Holick, 2009).

Steroid hormon $1,25(\mathrm{OH})_{2} \mathrm{D}_{3}$ reseptörü (D vitamini reseptörü), 38'in üzerinde dokuda yaygın olarak dağılmıştır. Aktive olan reseptör-DNA kalsiyum ve fosfat emilimini uyarmak da dahil olmak üzere $D$ vitamini genomik fonksiyonlarını yerine getiren proteinleri kodlayan genlerin transkripsiyonunu modüle etmektedir. Ayrıca kalsemik olmayan dokulardaki birçok genin ekspresyonunu düzenlemektedir. Bu kapsamlı D vitamini mekanizmasının genomik ve hızlı düzenleyici etkileri osteoporoz, kanser, tip-2 diyabet, ateroskleroz, vasküler hastalıklar, kalsifikasyon ve enfeksiyon gibi kronik yaşlanma hastalıklarının gecikmesinde önem taşımaktadır (Haussler ve ark., 2011).

D vitamini hormonu tarafından aktive edilen $1,25(\mathrm{OH})_{2} \mathrm{D}_{3}-\mathrm{D}$ vitamini hücresel reseptörünün (beyinde ve merkezi ve periferik sinir sisteminin çeşitli bölgelerinde) gen transkripsiyonunun regülasyonundaki önemi görülmüştür. Kritik hücresel koregülatör moleküllerinin gen ekspresyonunu kontrol ettiği ve splisozom ile birleşme yaptığına dair önemli bulgular ortaya çıkarılmıştır. Bu kompleksin sadece hücre dışı kalsiyum seviyelerini kontrol etmekle kalmayıp aynı zamanda kalsiyum sensörünün paratiroid bezlerinde ve böbrek de dahil olmak üzere diğer bazı dokularda ekspresyonunun modülasyonu yoluyla kalsiyuma hücresel tepkileri de kontrol ettiği ortaya koyulmuştur. Bunun sonucunda kusurlu $D$ vitamini endokrin sistemi ile hipertansiyon, kanser ve kanserojen olmayan hiperproliferatif bozukluklar, otoimmün hastalıklar (vücudun yanlışlıkla kendine saldırdığı durum) ve enfeksiyonlara yatkınlık arasındaki bağlantı daha iyi karakterize edilmiştir. Kemik yeniden şekillenmesi, böbrek ve bağırsak kalsiyum alımı veya paratiroid ve kondrosit büyümesi gibi birçok $D_{3}$ vitamini reseptörü 
bağımlı ve bağımsız mekanizma tanımlanmıştır (Mackay-Sim ve ark., 2004; Dusso ve ark., 2005).

Vitamin D'nin nörolojik sistemde hücre proliferasyonu, differansiyasyonu, nörotransmisyonu ve nöroplastisitede farklı değişken rollere sahip olduğu ve nörotrofik, nöroprotektif etki sağladığı belirtilmiştir (Yılmaz ve Yılmaz, 2013). D vitamininin nöron gelişimini teşvik ettiği (Brown ve ark., 2003), beyin gelişiminde ve fonksiyonlarındaki olumlu etkileri ve eksikliğinin olumsuz etkileri gösterilmiştir (Kesby ve ark., 2011; Groves ve ark., 2013). D vitamini eksikliği giderek daha fazla sayıda psikiyatrik durumla ilişkilendirilmektedir. D vitaminin bir nörosteroid olarak sınıflandırıldığı ve beyinle ilişkili Parkinson, Alzheimer, MS ve ALS gibi bazı hastalıkların gelişimiyle bağlantılı olduğu gösterilmektedir (McGrath ve ark., 2004; Eyles ve ark., 2013). Nörogelişimsel bozukluklar ve zihinsel yetersizliklerde (Grant ve ark., 2015), epilepsi (Pendo ve DeGiorgio, 2016), demans ve Alzheimer (Afzal ve ark., 2014), şizofreni (Mackay-Sim ve ark., 2004; Yüksel ve ark., 2014) gibi hastalıklar için D vitamininin olumlu katkıları vurgulanmaktadır.

D vitamini ile kanser hastalıklarının bağlantısı çok sayıdaki klinik çalışmalarla ortaya koyulmuştur (Woloszynska-Read ve ark., 2011). ABD'deki çalışmasında Grant (2002), erkeklerde ve kadınlarda UV maruziyeti ile kansere bağlı erken ölüm arasında dramatik bir zıt ilişki olduğunu bildirmiştir. Kanser mortalite oranlarının coğrafi varyasyonlar ve güneş UVB ışınlarına maruz kalmasındaki değişikliklere bağlanabileceğini göstermiştir. Buradan varılabilecek sonuç, özellikle yaz aylarında güneş UVB radyasyonuna güvenli ve dikkatli bir şekilde daha fazla maruz kalınarak D3 vitamini takviyesi ile birçok yaşamın uzatılabileceğidir.

\section{DOĞADA BULUNAN D VITAMINI KAYNAKLARI}

Bir milyar yıl önce okyanuslarda gelişmeye başlayan yaşam formları güneş ışığından karbonhidrat üretmek için bir enerji kaynağı olarak faydalanmışlardır. Sargasso Denizi'nde (Atlantik Okyanusu) 500 milyondan fazla bir süredir varlığını sürdüren Emiliania huxleyi (kalsiyum karbonat dış iskeletine sahip bir kokolittofor tür) dahil olmak üzere en eski fitoplanktonlardan bazıları, güneş ışığına maruz kaldığında, fotosentez sonucunda sadece glikoz değil, aynı zamanda $\mathrm{D}_{2}$ vitamini üretmişlerdir. $\mathrm{Bu}$ fitoplankton üyeleri, UVB radyasyonunu emer ve previtamin $D_{2}$ oluşturmak için bir fotoliz reaksiyonu geçirerek büyük miktarda ergosterol üretirler. Reaksiyon esnasında termodinamik olarak kararsız izomer oluşturulduktan sonra $D_{2}$ vitaminine dönüşümü gerçekleşmektedir (Wacker ve Holick, 2013). Benzer şekilde mayalar ve mantarlar da yüksek miktarda ergosterol içerir ve güneş ışığına maruz kaldıklarında $D_{2}$ vitamini üretirler (Keegan ve ark., 2013). Jasinghe ve ark., (2006) tarafından ışınlanmış mantarlar ile yapılan bir çalışmada, elde edilen $D_{2}$ vitamini ile beslenen fare deney hayvanlarının femur kemik mineral yoğunluğunun önemli ölçüde arttığı rapor edilmiştir.

Balıklar, besin zincirinde mikro-alglerden kaynaklı bir birikimden dolayı en yüksek doğal $D$ vitamini içeriğine sahiptir. Mikro-algler hem $D_{3}$ vitamini hem de provitamin $D_{3}$ içerir, bu da bitkiler aleminde ve alglerde de $D_{3}$ vitamininin var olduğunu göstermektedir. Provitamin $D_{2}$ (ergosterol) birçok mantar tarafından sentezlenir. Ren geyiği likeninin $D_{2}$ ve $D_{3}$ vitamini içerdiği gözlemlenmiştir. Bazı yüksek bitkiler tarafından da D vitamini sentezi yapılmaktadır (Björn ve Wang, 2000).

Gökkuşağı alabalığının (Oncorhynchus mykiss) derisinde, mavi ışık altında (380-480 nm) 7-DHK'den D vitamini oluştuğu tespit edilmiştir. Bu durumda $D_{3}$ vitamini veya $25(\mathrm{OH}) \mathrm{D}_{3}$ yerine $1,25(\mathrm{OH})_{2} \mathrm{D}_{3}$ birikmektedir. Alabalıkta, kara hayvanlarında olduğu gibi, kalsiterol böbreklerinde değil karaciğerinde sentezlenmektedir (Göring, 2018).

Ferguson ve ark. (2005) çalışmalarında, farklı sıcaklık ve ışık tercihleri olan 2 Anolis türünün (tropik kertenkele) yetişkin erkekleri için karşılaştırmalı olarak doğal UVB maruziyetini, $D$ vitamini besinini ve cilt tarafından üretilen D vitamini sentezini incelemişlerdir. Ortamdaki UV maruziyetine göre değişen intiyaçlarına bağı bir adaptasyon olarak derilerindeki $D$ vitamini üretimi seviyesinin değiştiği, ayrıca bunun davranışsal olarak düzenleme yetenekleri ile de ilişkili olabileceği belirtilmiştir.

Hayvanlarda, bitkilerde ve diğer organizmalarda $D$ vitamini birikimi hakkındaki verileri içeren yayınlar pek fazla değildir. Arktik ve subarktik bölgelerde genellikle $16{ }^{\circ} \mathrm{C}$ üzerine çıkmayan düşük sıcaklıklarda yaşayan ve besin zincirinde Ren geyiğinin ana besini olan Cladonia rangiferina'nın $\mathrm{D}_{3}$ ve $\mathrm{D}_{2}$ vitaminlerini biriktirdiği rapor edilmiştir. Yıllık büyüme hızı yaklaşık $15 \mathrm{~mm}$ kadar olan bu likenin metabolizma hızının yavaş olduğu koşullarda dahi previtamin D yoluyla provitamin D'yi (7-DHK ve ergosterol) $D_{3}$ ile $D_{2}$ vitaminine dönüştürebilmesi ilgi çekicidir (Göring, 2018). Geniş tundra alanlarında ve ışıklı tayga ormanlarında yetişen Ren geyiği likenlerinden bir diğeri Cladonia arbuscula'da D vitamini konsantrasyonlarının $100 \mathrm{~g}$ kuru materyalde $D_{3}$ için 67-204 $\mu \mathrm{g}$ ve $D_{2}$ için 2255 ․ k kadar olduğu kaydedilmiştir (Wang ve ark., 2001).

D vitamini kara hayvanlarında lanosterol $\left(D_{3}\right)$ yoluyla 7DHK, bitkilerde sikloartenol $\left(\mathrm{D}_{3}\right)$ yoluyla 7-DHK; mantarlarda lanosterol $\left(D_{2}\right)$ yoluyla ergosterol; alglerde ve siyanobakterilerde ise 7-DHK veya ergosterol $\left(D_{3}\right.$ veya $\left.D_{2}\right)$ sentezlenmektedir. D vitamini esas olarak pro-hormon 
gibi hareket ettiği organizmalarda, örneğin kara hayvanlarında birikim göstermektedir. Zorunlu olarak ihtiyaç duyulmasa da $D_{3}$ veya $D_{2}$ vitaminleri başka organizmalarda degradasyon ürünü olarak da bulunabilir. Bu tür ürünler, örneğin alg, mantar ve likenlerde metabolize edici enzimlerin yokluğu nedeniyle birikmektedir. Bazı organizmalar (örneğin zooplankton ve balık) ise beslenirken $\mathrm{D}$ vitaminleri alırlar; bu durumda, D vitaminleri biyolojik işlevleri yerine getiremez ve metabolize edilmezler, hücrelerde depolanırlar. İstisna olarak, gökkuşağı alabalığı ve nispeten yüksek miktarlarda aktif hormon kalsiterol ( $D$ vitamini değil) biriktiren sadece birkaç bitki türü rapor edilmiştir. Bu bitkilerin otlayan hayvanlar için çok toksik olduğu (enzootik kalsinoza neden olur) bilinmektedir (Göring, 2018).

Canlılarda ve gıdalardaki $D$ vitamini ve metabolitlerini ölçmek için, standart analitik metot olarak Yüksek Performanslı Sıvı Kromatografisi (HPLC) analizi sıklıkla kullanılmaktadır. Son zamanlarda özellikle bitkisel materyallerde düşük konsantrasyonları tespit etmek için özelleştirilmiş Sıvı Kromatografi Tandem Kütle Spektrometresinin (LC-MS/MS) hassas, spesifik ve güvenilir bir yöntem olduğu belirtilmektedir (Black ve ark. 2017).

\section{Öncü Vitamin D Sentezleyen Organizmalar}

Bitkiler ve poikilotermik hayvanların birkaç farklı provitamin $D$ formu içerdiği ve benzer şekilde mantarların da birden fazla provitamin D üretebildiği bilinmektedir (Keegan ve ark., 2013). Tablo 1'de çeşitli kaynaklara göre doğadaki canlılarda bulunan $D$ vitamini metabolitleri özetlenmiştir.

Bitkiler: Birçok bitkide endofitik mantarların varlığı bilinmektedir. Bu nedenle, mantar hücre zarında bulunan ergosterolün foto-dönüşümünün bir sonucu olarak bitkilerde $D_{2}$ vitamini bulunmuştur (Black ve ark., 2017). Ergosterol bitkilerde nadirdir ve bitki sterolleri ara madde sikloartenol yoluyla yapılır (Brumfield ve ark., 2017). Yüksek bitkilerde sikloartenolden sentezlenen 7-DHK genellikle sterollerin toplam içeriğinin sadece \% 1-2'sini oluşturan çok düşük konsantrasyonlarda bulunmaktadır (Hughes ve ark., 2018). $\mathrm{D}_{3}$ vitamini ve $25(\mathrm{OH}) \mathrm{D}_{3}$ esas olarak Solanaceae familyasında bulunmuştur, araştırmalar büyük miktarlarda zehirli olduğu bilinen yapraklara odaklanmıştır, yenilebilir meyvelerinde $D_{3}$ vitamini ve metabolitlerinin mevcut olup olmadığı ise henüz açık değildir. $D_{3}$ vitamini ve metabolitlerini ve nispeten büyük miktarlarda kalsiterol içeren bitkiler; Solanum malacoxyIon, Lycopersicon esculentum, S. tuberosum, S. melongena, Cucurbita pepo subsp. pepo convar. giromontina, $S$. glaucophyllum (bitkiler ve hücre kültürü), Nicotiana glauca, Cestrum diurnum ve Trisetum flavescens şeklinde sıralanmıştır (Göring, 2018). Nicotiana glauca'daki
D3 metabolitleri incelenmiş ve $\mathrm{D}_{3}$ ve $1,25(\mathrm{OH})_{2} \mathrm{D}_{3}$ bakımından zengin bulunmuştur (Skliar ve ark., 2000).

Algler: Yeşil, kahverengi ve kırmızı alglerde kolesterol ve 7-DHK sentezlenmektedir. Ayrıca çeşitli alg türlerinde, örneğin Dunaliella tertiolecta, Chlamydomonas reinhardtii, Chlorella vulgaris ve Cyanidium caldarium gibi, ergosterol bulunduğu rapor edilmiştir (Göring, 2018). Biyoinformatik ve genomik çalışmalar (Brumfield ve ark., 2017), yeşil alg Chlamydomonas reinhardtii Dangeard'in sterol üretiminde muhtemelen daha yüksek bitkilere çok benzer bir yol kullandığını ortaya çıkarmıştır. Chlamydomonas genomu, yüksek bitki Arabidopsis thaliana veya maya Saccharomyces cerevisiae ile karşılaştırılmış ve C. reinhardtii'nin ergosterol ve 7-dehidroporiferasterol biyosentezi için gerekli olan tüm genlere sahip olduğu gösterilmiştir. Buna göre Chlorophyta, Haptophyta, Rhodophyta, Bacillariophyta ve Phaeophyta gibi algler olarak bilinen organizmaların da aynı biyosentetik yolu kullanarak sikloartenol ara metabolit yoluyla steroller yapması muhtemel görünmektedir.

Mantarlar: Tüm mantarların karakteristiği, genellikle yüksek konsantrasyonlarda, ergosterol içeriğidir. Lanosterolden sentezlenen ergosterol, yabani ve yetiştirilen mantar türlerinin fruktifikasyonlarında baskın bir steroldür (Cardwell ve ark., 2018). Mantarlardaki en yaygın D vitamini formu $D_{2}$ olup UV maruziyetine bağlı olarak daha az miktarlarda $D_{3}$ ve $D_{4}$ vitaminleri (22-dihidroergokalsiferol) de içerebilirler (Phillips ve ark., 2012).

Kara hayvanları: İnsan dahil olmak üzere amfibilerden primatlara kadar çoğu kara hayvanında 7-DHK, UV ışığının etkisi altında $D$ vitamini sentezi için bir öncü görevi görür. Hayvanlarda, kolesterol lanosterolden oluşur (Holick, 1989; Göring, 2018). D $D_{3}$ vitamini hayvansal gıdalarda en yaygın formdur (Cardwell ve ark., 2018).

\section{Vitamin D Biriktiren Organizmalar ve Çevresel Fak- törlerin Etkisi}

D vitamini biriktirici kaynak olarak ilk sırada likenler gelmektedir. Tek hücreli organizmalar nihai ürün olarak $D$ vitamini biriktirirken ve kara hayvanları onu $25(\mathrm{OH}) \mathrm{D}_{3}$ şeklinde biriktirirler.

Likenler: Ergosterol ve 7-DHK'nin yanı sıra $D_{2}$ ve $D_{3}$ vitaminleri, Rusya'nın ve diğer ülkelerin $\left(57-70^{\circ} \mathrm{N}\right)$ kuzeyinde yaşayan Ren geyiği likeninde (Cladonia rangiferina) yüksek miktarda bulunmuştur. Bir mantar ve bir alg türünden (daha fazla da olabilir) oluşan bu simbiyotik organizma kışın Ren geyiği için ana besin kaynağı olarak besin zincirindeki ilk bağlantıyı oluşturur. $D_{2}$ ve $D_{3}$ vitaminlerini biriktiren likenlerin üst kısmını tüketerek beslenen Ren geyiği, insanlara ve yırtıcı hayvanlara yeterli miktarda D vitamini alma fırsatı vererek kas dokusunda D vitaminleri biriktirir. C. arbuscula ve $C$. rangiferina, ren 
geyiği ve karibu için önemli kış yemleridir. $D_{3}$ vitamini içeriği, özellikle kış aylarında hayvanlar için hayati bir $D$ vitamini kaynağıdır.

Ren geyiği likeninde (C. arbuscula) $100 \mathrm{~g}$ kuru materyalde $D_{3}$ vitamini miktarı $67-204 \mu \mathrm{g}$ ve $D_{2}$ miktarı ise 22 $55 \mu \mathrm{g}$ aralığında olup bu likeninin yüksek ergosterol içeriği de bulunmaktadır. Örneğin, yüksek D vitamini konsantrasyonuna (100 g taze madde başına $\mu \mathrm{g}$ ) sahip bazı gıda ürünleri için bilinen miktarlar karşılaştırılırsa; yumurta 0,4-12; peynir 1,25; tavuk karaciğeri 1,20 ; sığır karaciğeri $0-14,1$; ringa balığı 2,2-38,0; alabalık 4,2-34,5; mantarlar 0,3-30,0. Ren geyiği likeninin $D$ vitamini içeriği burada belirtilen tüm ürünleri aşmaktadır (Göring, 2018).

Doğal habitatlarındaki ışık yoğunluğuna bağlı olarak UV ile uyarılan likenlerde pigment üretiminin ve tallus içinde dağılımının değiştiği tespit edilmiştir (Buffoni Hall ve ark., 2002). Likenlerin biyotik ve abiyotik stres koşullarında hayatta kalmalarında 'güneş kremi' denilen melanik pigmentlerin önemli rolü olduğu tespit edilmiştir. Likenlerde doğal UV koruyucu maddelerin üretimindeki farklılıklar, likenlerin büyüdüğü çevresel koşullara bağlıdır. Yapılan gözlem ve incelemeler, üretilen metabolitlerin bu organizmaların ışık gibi dış stres faktörlerine karşı evrimsel bir tepkisi sonucu geliştiğine işaret etmektedir. Bu metabolitler, fotosentez için gerekli ışığı kesmeden, fazla UV ışınlarının emilmesini sağlar ve böylece likene zarar vermesini önlerler (Al-Amoody ve ark., 2020). Genellikle güneş koruyucular tek başlarına değil, DNA hasarını önleyebilen diğer UV filtreleri veya antioksidanlarla birlikte etkili olmaktadır. Buradan yola çıkılarak UVB emici pigmentlerin likenlerde $D$ vitamini üretiminde ve birikiminde belirleyici rolü olduğu düşünülebilir. Dolayısıyla bu maddelerin oluşumu ekolojik şartların farklılığı ile kendini göstermektedir. Likenin coğrafi konumuna ve yetişme ortamına bağlı olarak maruz kaldığı gün ışığı yoğunluğu oldukça önemlidir (Deduke ve ark., 2012). Örneğin Kuzey Finlandiya'dan Yunanistan'a farklı enlemlerden toplanan Cladonia arbuscula (Wallr.) Hale ve W.L. Culb. likeninin tallus içindeki $D$ vitamini içerikleri karşılaştırıldığında; farklı doğal koşullar altında UVB radyasyonu ile güçlü pozitif ilişki saptanmıştır (Wang ve ark., 2001).

Mantarlar: Güneş ışığına veya UVB radyasyonuna maruz kalan mantarlar, yüksek konsantrasyonlarda $D$ vitamini öncüsü provitamin $D_{2}$ içerdiğinden, mükemmel bir $D_{2}$ vitamini kaynağıdır. Mantarlar UV radyasyonuna maruz kaldığında provitamin $D_{2}$, previtamin $D_{2}$ ye dönüştürülür. Bir kez oluştuktan sonra previtamin $D_{2}$, insan derisinde previtamin $D_{3}$ 'ün $D_{3}$ vitaminine izomerleştiği şekilde hızla $D_{2}$ vitaminine izomerleşir. Mantarların UV radyasyonuna sürekli maruz kalması lumisterol ${ }_{2}\left(\mathrm{~L}_{2}\right)$ ve taşisterol $_{2}\left(T_{2}\right)$ üretimi ile sonuçlanır. Beyaz şapkalı mantarlarda $L_{2}$ konsantrasyonunun, üretildikten sonra 24 saate kadar sabit kaldığı $T_{2}$ konsantrasyonunun ise hızla düştüğü gözlenmiştir. Shiitake mantarlarının sadece $D_{2}$ vitamini üretmekle kalmayıp aynı zamanda $\mathrm{D}_{3}$ vitamini ve $\mathrm{D}_{4}$ vitamini de üretebildiği rapor edilmiştir.

Saklama koşulları ve pişirme yöntemi optimum vitamin değeri açısından önem taşımakla birlikte, mantarlar tüketildiğinde, 25-hidroksivitamin D kan seviyelerini sağlıklı bir aralıkta artırabilen ve koruyabilen zengin bir $D_{2}$ vitamini kaynağı olarak gösterilmektedir (Cardwell ve ark., 2018). Mantarların $D_{3}$ vitamini ve $D_{4}$ vitamini kaynağı da sağlayabileceği belirtilmektedir (Keegan ve ark., 2013). Bu nedenle mantarlar özellikle veganlar için mükemmel bir alternatif $D$ vitamini kaynağıdır. 
Tablo 1. Canlılarda bulunan $D$ vitamini metabolitleri

\begin{tabular}{|c|c|c|c|}
\hline Canlı grubu & Organizma & D vitamini metaboliti & Kaynak \\
\hline Algler & $\begin{array}{c}\text { Chlorella vulgaris, Cyanidium } \\
\text { caldarium } \\
\text { Chlamydomonas reinhardtii } \\
\text { Dunaliella tertiolecta }\end{array}$ & $\begin{array}{l}\text { ergosterol } \\
\text { Provitamin D2 } \\
\text { ergosterol } \\
\text { ergosterol }\end{array}$ & $\begin{array}{c}\text { (Göring, 2018) } \\
\text { (Kesby ve ark., 2011) } \\
\text { (Göring, 2018) }\end{array}$ \\
\hline \multirow[t]{3}{*}{ Bitkiler } & $\begin{array}{c}\text { Cucurbitaceae, Fabaceae, Poa- } \\
\text { ceae, Solanaceae familyaları }\end{array}$ & D3 & $\begin{array}{l}\text { (Göring, 2018; Hughes } \\
\text { ve ark., 2018) }\end{array}$ \\
\hline & $\begin{array}{l}\text { Solanum lycopersicum, } \\
\text { S. glaucophyllum }\end{array}$ & Provitamin D3 ve D3 & $\begin{array}{l}\text { (Jäpelt ve Jakobsen, } \\
\text { 2013) }\end{array}$ \\
\hline & Nicotiana glauca & $\mathrm{D} 3$ ve $1,25(\mathrm{OH})_{2} \mathrm{D}_{3}$ & $\begin{array}{l}\text { (Göring, 2018; Skliar } \\
\text { ve ark., 2000) }\end{array}$ \\
\hline Likenler & $\begin{array}{l}\text { Cladonia arbuscula, } \\
\text { C. rangiferina }\end{array}$ & D2, D3 & $\begin{array}{c}\text { (Göring, 2018; Wang } \\
\text { ve ark., 2001) }\end{array}$ \\
\hline Hayvanlar & $\begin{array}{c}\text { Anolis sagrei } \\
\text { Anolis lineotopus merope ker- } \\
\text { tenkeleleri }\end{array}$ & D3 & $\begin{array}{l}\text { (Ferguson ve ark., } \\
\text { 2005) }\end{array}$ \\
\hline \multirow[t]{3}{*}{ Mantarlar } & $\begin{array}{l}\text { Beyaz düğme, crimini, portabella } \\
\text { gibi isimlerle bilinen kültür man- } \\
\text { tarı (Agaricus bisporus) }\end{array}$ & D2 (\%88), D4 (\%12) & (Keegan ve ark., 2013) \\
\hline & $\begin{array}{c}\text { enoki-kış mantarı (Flammulina } \\
\text { velutipes), şitaki (Lentinula edo- } \\
\text { des), maitake (Grifola frondosa), } \\
\text { istiridye (Pleurotus ostreatus), } \\
\text { morel-kuzugöbeği (Morchella } \\
\text { esculenta), portabella (Cantha- } \\
\text { rellus cibarius) yenilebilen man- } \\
\text { tarlar }\end{array}$ & $\begin{array}{l}\text { D2, D3, D4 (22-dihyd- } \\
\text { roergocalciferol) }\end{array}$ & $\begin{array}{l}\text { (Keegan ve ark., 2013; } \\
\text { Cardwell ve ark., 2018; } \\
\text { Phillips ve ark., 2012) }\end{array}$ \\
\hline & $\begin{array}{c}\text { Saccharomyces cerevisiae } \\
\text { maya }\end{array}$ & D2 (\%99), D4 (\%1) & (Keegan ve ark., 2013) \\
\hline
\end{tabular}

\section{SONUÇ VE ÖNERILER}

Son yıllardaki D vitamini biyoaktivasyonu hakkındaki bulgular, D vitamini endokrin sisteminin kalsiyum homeostazı ve kemik metabolizmasında önemli bir role sahip olmasına ilaveten, hücre farklılaşmasının indüklenmesi, hücre büyümesinin inhibisyonu, immünomodülasyon ve diğer hormonal sistemlerin kontrolünü içeren çeşitli biyolojik eylemlerle ve hastalık önleme ile ilişkisinin anlaşımasını sağlamıştır. D vitamini kalsiyum ve fosforun sindirim yollarında (böbrek, bağırsak) kullanımı ve emilimi için gerekli çok önemli bir vitamindir. Yapılan araştırmalar D vitaminin hipertansiyon, kanser, otoimmün hastalıklar ve enfeksiyonlara karşı hastalık önleyici rolünü vurgulamaktadır.

D vitamini eksikliği, dünya çapında iskelet ve kronik hastalık riskini artıran bir pandemiktir. D vitamini eksikliği bakımından riskli gruplar arasında; yaşlılar, yetersiz güneş ışığı maruziyeti olanlar, koyu cilt rengine sahip olanlar, D vitamini biyoyararlanımını azaltıcı obezite, osteoporoz, osteomalazi, hiperparatroidi, kronik böbrek yetmez- liği, kronik karaciğer hastalığı, malabsorbsiyon sendromları gibi hastalıkları olanlar önde gelmektedir (Öncül Börekçi, 2019).

D vitamini eksikliğinde rolü olan ekolojik ve kültürel faktörler olarak çeşitli kaynaklara göre (Holick, 2007; Acarkan, 2015; Çalışkan Özçelik ve ark., 2012) şunlar sayılabilir: İklimsel faktörler (yetersiz güneş ışığı maruziyeti), güneşten korunma metotları, giyinme şekilleri, cildin pigmentasyonu (koyu cilt rengi), diyetle yetersiz D vitamini alımı, yaşıııı, aşırı korunan yenidoğanlar, genetik hastalıklar (rikets gibi), yağ malabsorbsiyon sendromları, inflamatuar enfeksiyonel kronik bağırsak hastalıkları (whipple, crohn gibi), kronik böbrek hastalığı, karaciğer yetmezliği, obezite, kistik fibrozis, çölyak gibi hastalıklar.

Bu nedenle, bilinçli şekilde güneşe maruz kalmak ve doğal ya da takviyeli olarak $D$ vitamini içeren gıdalarla beslenmek sağlıklı bir yaşam tarzı sürdürebilmenin önemli bir şartı olarak kabul edilmektedir (Keegan ve ark., 2013).

$D$ vitamini, metabolik fonksiyonların sürdürülmesi ve iskelet sağlığı için kalsiyum ve fosfat metabolizmasının 
düzenlenmesinde önemli bir rol oynamaktadır. Vücuttaki çoğu hücre ve organ $D$ vitamini reseptörüne sahip olup birçok hücre ve organ 1,25-dihidroksivitamin $D$ üretebilmektedir. Sonuçta 1,25-dihidroksivitamin D ile ilişkili çok sayıda biyolojik yolu etkilemektedir. Ancak günümüzde artan D vitamini eksikliği bir küresel pandemi olarak kabul edilmektedir. Yüksek enlemlerde yaşayanlarda artan D vitamini eksikliği riski, otoimmün hastalıklar, bazı kanserler, kardiyovasküler hastalık, bulaşıcı hastalıklar, şizofreni ve tip 2 diyabet gibi birçok kronik hastalık ile ilişkili olarak öne çıkmaktadır (Wacker ve Holick, 2013).

Toplumda D vitamini eksikliğinin azaltılması ile ilgili olarak göz önünde bulundurulması gereken genel öneriler şu önemli maddeler halinde sıralanabilir:

- Yeterli miktarda ve sürede güneş ışığına maruz kaIınması

- Güneş ışığından yararlanmayı engelleyecek hava kirliliği düzeyine karşı önlemler üzerinde durulması

- Yeterli D vitamini seviyesini koruyan sağlıklı beslenme konusunda farkındalık oluşturulması

- Doğal ekosistemlerin korunması ve sürdürülebilirliğinin sağlanması

- Organik ürün elde edilebilecek doğal kaynakların korunması

- Sürdürülebilir sağlıklı çevre bilincinin yaygınlaştırılması

Küresel D vitamini eksikliğini ve olumsuz sağlık sonuçlarını önlemek için, bilinçli güneşe maruz kalma önerileri ve gerektiğinde $D$ vitamini takviyesi alımını teşvik eden gıda takviye programlarını artırmaya yönelik uygulamalar yapılabilir. Bunun yanı sıra tüm doğal ürünlerde olduğu gibi asıl kaynağın doğadan geldiğinin unutulmaması ve biyolojik çeşitliliğin korunmasına özen gösterilmelidir.

Son zamanlarda doğadaki canlılardan insan intiyaçlarını karşılamak için organik ürünler elde edilmesi önem kazanmıştır. Bu bağlamda D vitamini kaynağı olarak da doğal kaynaklardan yararlanma fikri öne çıkmaktadır. Doğada pek çok organizmanın UVB ışınlarının etkisiyle D vitamini türevlerini metabolik ürün olarak sentezlediği veya besin zinciri sonucunda vücudunda biriktirebildiği tespit edilmiştir. Bugüne kadar yapılan çalışmalarda, hayvansal ya da bitkisel organizmaların yanında mantarlar ve likenlerin de zengin doğal $D$ vitamini kaynağı olabileceği gösterilmektedir.

D vitamini biriktiricilerde önde gelen likenler için; likenlerin ortak yaşam birliğinden oluşmaları dikkate alınarak ortakyaşarların ayrı ayrı analiz edilmesi ve etkileşimlerinin araştırılması önemlidir. Wang ve ark. (2001) ren geyiklerinin ana besinini oluşturan liken türlerinden ikisi
(Cladonia arbuscula ve $C$. rangiferina) ile yaptıkları çaIışmada, farklı doğal habitat koşullarında gelişen türlerde D vitamini biyosentezinin ışığa bağlı bir olay olduğu net biçimde ortaya konulmuştur. Yüksek oranda UVB filtresi görevi gören usnik asit gibi liken maddeleri içermeleriyle bağlantılı olarak türler arasındaki $D$ vitamini seviyelerinin değişiklik göstermesi muhtemeldir. Bununla birlikte, kemotaksonomik olarak farklılaşan liken türlerinde ve hayvan dokularında $D_{3}$ vitamini varlığının daha fazla araştırılması önem taşımaktadır.

Doğadaki canlılarda D vitamini sentez mekanizmalarının ve biyosentez sürecini etkileyen faktörlerin anlaşıması, bu canlılardan insanların D vitamini kaynağı olarak yararlanılabilmesi ve sağlıklı yaşamı desteleyecek doğal ürünlerin elde edilebilmesi için önemlidir.

\section{KAYNAKLAR}

Acarkan, T. (2015). D Vitamini. Journal of Complementary Medicine, Regulation and Neural Therapy, 9(3): 5-8.

Afzal, S., Bojesen, S.E., Nordestgaard, B.G. (2014). Reduced 25-hydroxyvitamin $D$ and risk of Alzheimer's disease and vascular dementia. Alzheimer's \& Dementia, 10(3): 296302.

Akkoyun, H.T., Bayramoğlu, M., Ekin, S., Çelebi, F. (2014). D Vitamini ve Metabolizma İçin Önemi. Atatürk Üniversitesi Vet. Bil. Derg. 9(3): 213-219.

Al-Amoody, A.A., Yayman, D., Kaan, T., Özkök, E.A., Özcan, A., Özen, E., Çobanoğlu Özyiğitoğlu, G. (2020). Role of Lichen Secondary Metabolites And Pigments In UV-Screening Phenomenon In Lichens. Acta Biologica Turcica 33(1): 35-48.

Björn, L.O., Wang, T. (2000). Vitamin D in an ecological context. Int J Circumpolar Health, 59(1): 26-32.

Black, L.J., Lucas, R.M., Sherriff, J.L., Björn, L.O., Bornman, J.F. (2017). In Pursuit of Vitamin D in Plants. Nutrients, 9: 136.

Brown, J., Bianco, J.I., McGrath, J.J., Eyles, D.W. (2003). 1,25Dihydroxyvitamin D3 induces nerve growth factor, promotes neurite outgrowth and inhibits mitosis in embryonic rat hippocampal neurons. Neurosci Lett 343: 139-143.

Brumfield, K.M., Laborde, S.M., Moroney, J.V. (2017). A model for the ergosterol biosynthetic pathway in Chlamydomonas reinhardtii, European Journal of Phycology 52(1): 64-74.

Buffoni Hall, R.S., Bornman, J.F., Bjorn, L.O. (2002). UV-induced changes in pigment content and light penetration in the fruticose lichen Cladonia arbuscula ssp. mitis. Journal of Photochemistry and Photobiology, 66: 13-20.

Cardwell, G., Bornman, J.F., James, A.P., Black, L.J. (2018). A Review of Mushrooms as a Potential Source of Dietary Vitamin D. Nutrients, 10: 1498.

Chubarova, N., Zhdanova, Y. (2013). Ultraviolet resources over Northern Eurasia. Journal of Photochemistry and Photobiology B: Biology, 127: 38-51.

Çalışkan Özçelik, D., Koçer H., Kasım İ., Şencan İ., Kahveci R., Özkara A. (2012). D Vitamini. Turkish Medical Journal 6(2): 61-67. 
Deduke, C., Timsina, B., Piercey-Normore, M.D. (2012). Effect of Environmental Change on Secondary Metabolite Production In Lichen Forming Fungi. In: Young S., (Ed.) International Perspectives on Global Environmental Change. InTech, 197-230.

Dusso, A.S., Brown, A.J., Slatopolsky, E. (2005). Vitamin D. Am J Physiol Renal Physiol 289: F8-F28.

Eyles, D.W., Burne, T.H.J., McGrath, J.J. (2013). Vitamin D, effects on brain development, adult brain function and the links between low levels of vitamin $D$ and neuropsychiatric disease. Frontiers in Neuroendocrinology 34: 47-64.

Ferguson, G.W., Gehrmann, W.H., Karsten, K.B., Landwer, A.J., Carman, E.N., Chen, T.C., Holick, M.F. (2005). Ultraviolet Exposure and Vitamin D Synthesis in a Sun-Dwelling and a Shade-Dwelling Species of Anolis: Are There Adaptations for Lower Ultraviolet B and Dietary Vitamin D3 Availability in the Shade? Physiological and Biochemical Zoology 78(2): 193-200.

Fidan, F., Alkan, B.M., Tosun, A. (2014). Çağın Pandemisi: D Vitamini Eksikliği ve Yetersizliği. Türk Osteoporoz Dergisi 20: 71-74.

Göring, H. (2018). ISSN 0006_2979, Biochemistry (Moscow), 2018, Vol. 83, No. 11, pp. 1350_1357. (C) Pleiades Publishing, Ltd., 2018. Original Russian Text @ H. Göring, 2018, published in Biokhimiya, 83(11):1663-1672.

Grant, W.B. (2002). An Estimate of Premature Cancer Mortality in the U.S. Due to Inadequate Doses of Solar Ultraviolet-B Radiation. Cancer, 9(6): 1867-1875.

Grant, W.B., Wimalawansa, S.J., Holick, M.F., Cannell, J.J., Pludowski, P., Lappe, J.M., Pittaway, M., May, P. (2015). Emphasizing the Health Benefits of Vitamin D for Those with Neurodevelopmental Disorders and Intellectual Disabilities. Nutrients, 7: 1538-1564.

Grigalavicius, M., Juzeniene, A., Baturaite, Z., Dahlback, A., Moan, J. (2013). Biologically efficient solar radiation Vitamin $D$ production and induction of cutaneous malignant melanoma. Dermato-Endocrinology, 5(1): 150-158.

Groves ,N.J., Kesby, J.P., Eyles, D.W., McGrath, J.J., MackaySim, A., Burne, T.H.J. (2013). Adult vitamin D deficiency leads to behavioural and brain neurochemical alterations in C57BL/6J and BALB/c mice. Behavioural Brain Research, 241: 120- 131.

Gürbüz, P., Yetiş, G., Yakupoğulları, A. (2015). D Vitamini: İnsan Vücudunda Etkinliği Ve Eksikliği. Inönü Üniversitesi Sağlık Hizmetleri Meslek Yüksek Okulu Dergisi, 3(2): 7-11.

Haussler, M.R, Jurutka, P.W., Mizwicki, M., Norman, A.W. (2011). Vitamin D receptor (VDR)-mediated actions of 1a,25(OH)2vitamin D3: Genomic and non-genomic mechanisms. Best Practice \& Research Clinical Endocrinology \& Metabolism, 25: 543-559.

Henry, H.L. (2011). Regulation of vitamin D metabolism. Best Practice \& Research Clinical Endocrinology \& Metabolism, 25: $531-541$.

Holick, M.F. (1989). Phylogenetic and evolutionary aspects of vitamin D from phytoplankton to humans, in Vertebrate Endocrinology: Fundamentals and Biomedical Implications (Pank P.K.T., Schreibman M.P., eds.) Academic Press, Orlando, FL, 7-43.

Holick, M.F., Tian, X.Q., Allen, M. (1995). Evolutionary importance for the membrane enhancement of the production of vitamin D3 in the skin of poikilothermic animals. Proc. Natl. Acad. Sci. 92, 3124-3126.
Holick, M.F. (2007). Vitamin D Deficiency. The new england journal of medicine, 357: 266-81.

Holick, M.F. (2009). Vitamin D and Health: Evolution, Biologic Functions, and Recommended Dietary Intakes for Vitamin D. Clinic Rev Bone Miner Metab, 7: 2-19.

Hughes, L.J., Black, L.J., Sherriff, J.L., Dunlop, E., Strobel, N., Lucas, R.M., Bornman, J.F. (2018). Vitamin D Content of Australian Native Food Plants and Australian-Grown Edible Seaweed. Nutrients, 10: 876.

Jäpelt, R.B., Jakobsen, J. (2013). Vitamin D in plants: a review of occurrence, analysis, and biosynthesis. Frontiers in Plant Science, 4(136): 1- 20.

Jasinghe, V.J., Perera C.O., Barlow, P.J. (2006). Vitamin D2 from Irradiated Mushrooms Significantly Increases Femur Bone Mineral Density in Rats, Journal of Toxicology and Environmental Health, Part A, 69(21): 1979-1985.

Keegan, Raphael-John, H., Lu, Z., Bogusz, J.M., Williams, J.E., Holick, M.F. (2013). Photobiology of vitamin D in mushrooms and its bioavailability in humans, Dermato-Endocrinology, 5(1): 165-176.

Kesby, J.P., Eyles, D.W., Burne, T.H.J., McGrath, J.J. (2011). The effects of vitamin $D$ on brain development and adult brain function. Molecular and Cellular Endocrinology, 347: 121-127.

Kozlov, A., Khabarova, Y., Vershubsky, G., Ateeva, Y., Ryzhaenkov, V. (2014). Vitamin D status of northern indigenous people of Russia leading traditional and "modernized" way of life. Int J Circumpolar Health, 73: 26038.

Mackay-Sim, A., Fe'ron, F., Eyles, D., Burne, T., McGrath, J. (2004). Schizophrenia, Vitamin D, and Brain Development. International Review of Neurobiology, 59: 351-380.

McGrath, J.J., Feron, F.P., Burne, T.H., Mackay-Sim, A., Eyles, D.W. (2004). Vitamin D3 implications for brain development. J Steroid Biochem Mol Biol 89-90: 557-560.

Öncül Börekçi, N.(2019). D Vitamini eksikliği ile ilgili güncel bilgiler. Jour Turk Fam Phy 10(1): 35-42.

Pendo, K., DeGiorgio, C.M. (2016). Vitamin D3 for the Treatment of Epilepsy: Basic Mechanisms, Animal Models, and Clinical Trials. Front Neurol 8(7): 218.

Phillips, K.M., Horst, R.L., Koszewski, N.J., Simon, R.R. (2012). Vitamin D4 in Mushrooms. PLOS ONE 7(8): e40702.

Pludowski, P., Holick, M.F., Grant, W.B., Konstantynowicz, J., Mascarenhas, M.R., Haq, A., Povoroznyuk, V., Balatska, N., Barbosa, A.P., Karonova, T., Rudenka, E., Misiorowski, W., Zakharova, I., Rudenka, A., Łukaszkiewicz, J., Marcinowska-Suchowierska, E., Łaszcz, N., Abramowicz, P., Bhattoa, H.P., Wimalawansa, S.J. (2018). Vitamin D supplementation guidelines. Journal of Steroid Biochemistry \& Molecular Biology 175: 125-135.

Skliar, M., Curino, A., Milanesi, L., Benassati, S., Boland, R. (2000). Nicotiana glauca: another plant species containing vitamin D(3) metabolites. Plant Sci 156(2): 193-199.

Wacker, M., Holick, M.F. (2013). Sunlight and vitamin D: a global perspective for health, Dermatoendocrinology, 5:51108.

Wang, T., Bengtsson, G., Kärnefelt, I., Björn, L.O. (2001). Provitamins and vitamins D2 and D3 in Cladina spp. over a latitudinal gradient: possible correlation with UV levels. Journal of Photochemistry and Photobiology B: Biology, 62(1-2): 118-122. 
Woloszynska-Read, A., Johnson, C.S., Trump, D.L. (2011). Vitamin D and cancer: Clinical aspects. Best Practice \& Research Clinical Endocrinology \& Metabolism, 25: 605-615.

Yılmaz, M., Yılmaz, N. (2013). D Vitaminin beyindeki rolü ve ilişkili nörolojik hastalıklar-The role of vitamin $\mathrm{D}$ in the brain and related neurological diseases. Journal of Clinical and Experimental Investigations, 4(3): 411-415.
Yüksel, R.N., Altunsoy, N., Tikir, B., Külük, M.C., Unal, K., Goka, S., Aydemir, Ç., Goka, E. (2014). Correlation between total vitamin D levels and psychotic psychopathology in patients with schizophrenia: therapeutic implications for add-on vitamin D augmentation. Ther Adv Psychopharmacol 4(6): 268-275. 